\title{
Evaluation of clinician's input in surgical pathology process in a developing country
}

\section{Uchendu Obiora Jude ${ }^{1,2}$}

${ }^{\prime}$ Department of Histopathology, Delta State University Teaching Hospital, Oghara, Nigeria

${ }^{2}$ Department of Morbid Anatomy, Delta State University, Abraka, Nigeria

\section{Keywords: \\ Clinical information; Clinician; Surgical pathology process;}

\begin{abstract}
Background: The clinician's role is paramount in surgical pathologist's evaluation of surgical specimens. The study aims at evaluating clinicians' role in the surgical pathology process in Nigeria.

Materials and Methods: This is a three-year (2016-2018) study of all (1262) routines surgical pathology specimens (SPS) received at the histopathology department of Delta State University Teaching Hospital Oghara. Parameters analyzed include the quality of the containers and fixatives used during specimen submission and the information supplied by the clinician (Specimen nature, patients' age, gender, address, , hospital number, phone number and clinical information. The information was analyzed using Microsoft Excel 2017 and the result presented in tables.

Results: Nine (0.6\%) SPS were not stored in appropriate fixative while in $88(8.3 \%)$ cases, the quantity of fixatives were inadequate. Forty (3.2\%) of sample containers were inadequate while $86(6.8 \%)$ of the sample labels were wrongly placed. Fifty-two containers accommodated more than one SPS. The gender, age, address, hospital number, time of collection in day and hour were omitted in $21(1.7 \%), 18(1.4 \%)$, $627(49.7 \%) 921(73.0 \%)$ and 58(4.6\%) of the cases respectively. The clinical request form, clinical findings, previous investigations, previous treatment history and presumptive or definitive diagnosis were missing in 288(22.8\%), 192(15.2\%), 282(22.4\%),424(33.6\%),340(27.0\%) and 98(7.7\%) cases respectively. Their names, contact telephone numbers and signature were omitted in the request in 58(4.6\%), 1230(97.5\%) and $143(11.3 \%)$ of the cases respectively.

Conclusions: Among the parameters evaluated, Clinicians are mostly non-compliant in providing clinical information and their phone numbers. Continuous education and interaction with clinicians, computerized information management system and introduction of non-conformity registrar are possible ways of closing this gap.
\end{abstract}

\section{Correspondence:}

Dr Uchendu Obiora Jude MBBS, FWACP

Senior lecturer, Department of Histopathology,

Delta State University Teaching Hospital, Oghara, Nigeria

Department of Morbid Anatomy, Delta State University, Abraka, Nigeria ORCID ID: 00000001-5432-1342

Email: ojlinksent@yahoo.com

Received : $14^{\text {th }}$ October $2019 ;$ Accepted : February $15^{\text {th }} 2020$

Citation: Jude UO. Evaluation of clinician's input in surgical pathology process in a developing country. J Pathol Nep 2020;10:1608-12 DOI 10.3126/jpn.v10i1.25929

Copyright: This is an open-access article distributed under the terms of the Creative Commons Attribution 4.0 International License, which permits unrestricted use, distribution, and reproduction in any medium, provided the original author and source are credited.

\section{INTRODUCTION}

Willaim Osler, succinctly summarized the role of Pathology in modern medicine in his statement "As is our Pathology, so is our practice...." This central role of pathology is supported by the reports that $70 \%$ of decision in diagnosis and treatment of patient requires a pathology investigation. ${ }^{2}$

Surgical pathology is that branch of pathology involved in examining surgical or autopsy specimens with the aim of producing a timely, correct and complete diagnosis. These

DOI : 10.3126/jpn.v10i1.25929 
biological specimens are unique, delicate and irreplaceable, necessitating optimal handling.

The surgical pathologists' diagnosis is a subjective evaluation, whose success depends on his co-ordination of clinicians' input, gross specimen evaluation and microscopic examination of the specimen. The clinicians play pivotal role in deciding the patient that will benefit from surgery, tissue specimen selection, fixation, labeling and transportation; and in providing the pathologists with patients' vital information, specimens and clinical information. ${ }^{3}$ Improper handling of these roles may influence subsequent stages of the surgical pathology process with possible negative consequences. These include increased workload in the laboratory, increase in turn-around time, resource wastage, unsatisfactory or inaccurate diagnosis, compromised patient safety, poor image of the healthcare system to the public and laboratory errors that may lead to lawsuits. ${ }^{4,5}$

To the best of my knowledge, there have been limited studies in Nigeria documenting the clinicians' input in the surgical pathology process. The present study is the first of such study in Delta State of Nigeria aimed at evaluating and accessing the clinicians' role in surgical pathology. The result of the study will guide the hospital management and policy makers in intervening appropriately.

\section{MATERIALS AND METHODS}

Delta State University Teaching Hospital (DELSUTH) is a tertiary care centre, located in the Niger-Delta region of Nigeria. The study is a prospective descriptive study conducted over a three-year period (2016-2019), involving routine surgical specimen (requiring only hematoxylin and eosin staining) submitted to the histopathology department of DELSUTH. During each specimen grossing, these surgical specimens were evaluated for the quality of the transportation medium (container type, container size relative to the specimen, information on container label, position of container label, number of biopsy specimen on each container), the adequacy of fixative used (presence or absence of fixative, type of fixative used, ratio and level of fixative to the specimen) and the quality of information provided by the clinician ( patients biodata, specimen nature, time of specimen collection, patient's clinical information and originator's name, telephone number and signature).

The information extracted was analyzed using Microsoft Excel 2007 spreadsheet and the results presented in table . The originators of these requests (clinicians) were not aware that this study was being done. The approval for this study was received from the DELSUTH research ethics committee.

\section{RESULTS}

During the study period, a total of 1262 routine surgical specimen were randomly selected for this study. The sketch of the surgical pathology process from patient selection to result utilization for routine specimens is shown in Figure 1.

In $9(0.6 \%)$ of the cases, these specimen were received in normal saline instead of routine fixative. In $88(8.3 \%)$ of the cases, the specimens were not completely submerged within the fixatives. Forty $(3.2 \%)$ of the containers were either too small or their mouth is too small to access the specimen. In $86(6.8 \%)$ cases, the specimens labels were placed on the lid of the containers while in $55(4.5 \%)$ cases, two surgical specimens were submitted within the same container. Information such as specimen type, sex and age were missing in $9(0.9 \%), 67(5.3 \%)$ and $79(6.3 \%)$ of the container labels. (Table 1)

Table 2 shows the frequency and percentage of surgical specimen lacking information on patient;s biodata and the nature of the specimens. While all laboratory request forms submitted to the laboratory had patients' name, the gender, age, address, hospital number, time of collection in day and hour were omitted in 21(1.7\%), 18(1.4\%), 627(49.7\%), $921(73.0 \%)$ and $58(4.6 \%)$ of the cases respectively.

Deficiencies in clinical information provided by the clinician in the laboratory request forms were depicted in table 3 . The clinical history, clinical findings, previous investigations, previous treatment history and presumptive diagnosis were missing in 288(22.8\%), 192(15.2\%), 282(22.4\%),

Table 1: : storage medium/transport medium

\begin{tabular}{lccc}
\hline Parameter & & Frequency & Percentage \\
\hline Fixative & Specimen not completely submerged & 88 & $7.0 \%$ \\
& No/inappropriate fixative & 9 & $0.7 \%$ \\
\hline $\begin{array}{l}\text { Defective Container } \\
\text { Properties }\end{array}$ & Information placed at lid of container & 106 & $8.4 \%$ \\
& Inappropriate container(size, material) & 40 & $3.2 \%$ \\
\hline $\begin{array}{l}\text { Patient's information on } \\
\text { container label }\end{array}$ & Multiple biopsy in same container & 55 & $4.4 \%$ \\
& No name stated & Nil & $0 \%$ \\
& No age stated & 79 & $6.3 \%$ \\
& No Sex stated & 67 & $5.3 \%$ \\
\end{tabular}




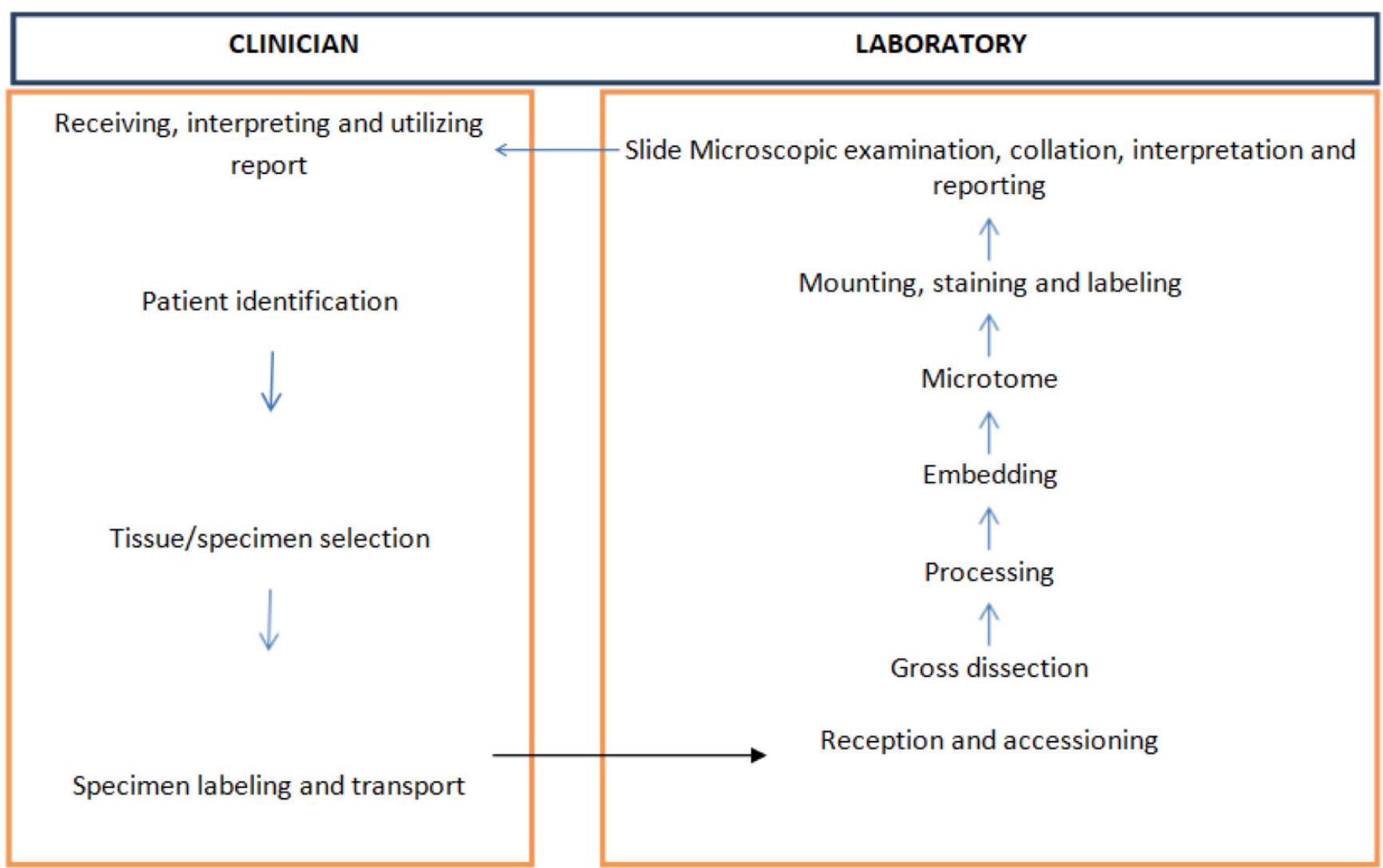

Figure 1: The surgical Pathology process and the relationship with Clinician.

Table 2: Patients' demographics and specimen information $(n=1262)$

\begin{tabular}{lcc}
\hline BIODATA & Not Provided & Percentage (\%) \\
PARAMETERS & Nil & Nil \\
\hline Name & 21 & 1.67 \\
\hline Gender & 18 & 1.43 \\
\hline Age & $\mathbf{6 2 7}$ & 49.7 \\
\hline Address & $\mathbf{1 0 5}$ & $\mathbf{8 . 3}$ \\
\hline Hospital number & $\mathbf{5 2}$ & $\mathbf{4 . 5}$ \\
\hline Anatomic site & $\mathbf{5 8}$ & $\mathbf{4 . 6}$ \\
\hline Date collected & $\mathbf{9 2 1}$ & $\mathbf{7 3}$ \\
\hline Time collected & & \\
\hline
\end{tabular}

Table 3: Adequacy of clinical information $[n=456]$

\begin{tabular}{lcc}
\hline $\begin{array}{l}\text { CLINICAL } \\
\text { INFORMATION }\end{array}$ & $\begin{array}{c}\text { Grossly } \\
\text { adequate/Absent }\end{array}$ & $\begin{array}{c}\text { Percentage } \\
(\%)\end{array}$ \\
\hline Clinical history & 288 & 22.8 \\
\hline Clinical findings & 192 & 15.2 \\
\hline $\begin{array}{l}\text { Relevant } \\
\text { investigation }\end{array}$ & 232 & 18.4 \\
\hline $\begin{array}{l}\text { Previous treatment } \\
\text { history }\end{array}$ & $\mathbf{4 2 4}$ & $\mathbf{3 3 . 6}$ \\
\hline $\begin{array}{l}\text { Previous histology/ } \\
\text { cytology }\end{array}$ & $\mathbf{3 4 0}$ & $\mathbf{2 7 . 0}$ \\
\hline $\begin{array}{l}\text { Presumptive/ } \\
\text { differential diagnosis }\end{array}$ & $\mathbf{9 8}$ & $\mathbf{7 . 8}$ \\
\hline
\end{tabular}

\begin{tabular}{lcc}
$\begin{array}{l}\text { Table 4: Adequacy of investigation originator's } \\
\text { information }\end{array}$ & Percentage \\
\hline $\begin{array}{l}\text { Originators' } \\
\text { Information }\end{array}$ & $\begin{array}{c}\text { Cases with } \\
\text { information } \\
\text { deficits }\end{array}$ & $4.6 \%$ \\
\hline $\begin{array}{l}\text { Originator's name } \\
\text { Originator's phone } \\
\text { no }\end{array}$ & 58 & $97.5 \%$ \\
\hline $\begin{array}{l}\text { Originator's } \\
\text { signature }\end{array}$ & 1230 & $11.3 \%$ \\
\hline
\end{tabular}

424(33.6\%), 340(27.0\%) and 98(7.7\%) cases respectively.

Deficiencies in the originators' information are shown in table 4. Their names, contact telephone numbers and signature were omitted in the request in 58(4.6\%), $1230(97.5 \%)$ and $143(11.3 \%)$ of the cases respectively.

\section{DISCUSSION}

Basically, the information expected of the clinician in the surgical pathology request form consists of (but not limited to) the biodata, specimen nature and the patients' clinical information. This invariably serves as a miniature referral note to convey the relevant information about the patient that is required by the pathologist, to ensure that the pathologist understands holistically the clinical problem 


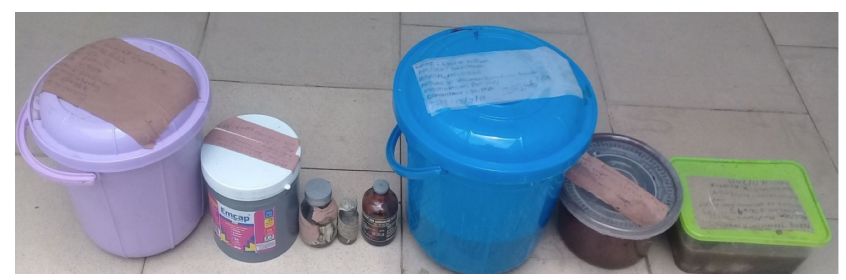

Figure 2: Saamples of inappropriate containers used for submitting surgical specimens.

he is expected to solve. Legally, this document is also a contract paper between the originator of the request and the laboratory. It is therefore on the best interest of the clinician and the patient that these rules are strictly followed. As has been earlier stated, the collaboration between the clinician and pathologist is necessity for improved patient care. ${ }^{6}$ By guiding the pathologist appropriately, his diagnosis is tailored more appropriately to the clinician's need and the patient has better opportunity of enjoying positive health outcome. This inter-relationship is aptly illustrated in figure 1.

In our study, the proportion of specimens without fixatives or only partly submerged in it are lower than $20 \%$ and $23.5 \%$ respectively reported Nwafor and Obioha; and Atanda and Raphael respectively. Ten perent buffered formalin is the routinely used general purpose and relatively affordable fixative in surgical pathology practice. An adequate fixative should be 15-20 times the volume of tissue. ${ }^{7}$ Inadequate or non-usage of fixatives can lead to tissue deterioration, erroneous result and delay in turn-around time (TAT) or sometimes result in a repeat biopsy. ${ }^{8}$ In this study, most nonsubmerged specimens are usually large specimens such as amputations and gynecologic tumours, a possible indication of a relationship between this behavior and volume of formalin provided in the theatre.

Specimens submitted in inappropriate containers were also observed by other researchers. Our report is lower than $11 \%, 16.5 \%$ and $29 \%$ reported by Nwafor and Obioha, Akanda and raphael, and Muhammad et al. respectively. Inappropriate container increases the risk of spillage of formalin in the laboratory. It also increases the workload of the laboratory staff as it sometimes takes a tougher task to extract these specimens from the containers. When specimens are labeled only on the container cover, cases where the lid falls off may result in loss of specimen identity. Clinicians involved in any of this ugly practice should be immediately contacted and the danger of this recklessness politely explained to them. ${ }^{7}$

Our cases with omitted gender is lower than $3 \%, 7.7 \%$ and $25 \%$ reported by Nwafor and Obioha, ${ }^{5}$ Forae and Obaseki, ${ }^{10}$ and Atanda and Raphael ${ }^{4}$ respectively. Our $1.43 \%$ deficit in documentation in age of patient is lower than 3\% and $15.9 \%$ recorded by Nwafor and Obioha; ${ }^{5}$ and Forae and Obaseki ${ }^{10}$ respectively. Some disease pattern often correlates consistently with age and sex of patients. This could be of immense benefit to the pathologist in excluding some close diagnostic differentials. ${ }^{11}$ It can also help the laboratory in relating with previous laboratory results, especially when it is not stated in the index case. Level of documentation has important implication on research.

It is worrisome that in this study, about half of the request forms do not have the patient's address. This is however lower that $63.6 \%$ reported by Forae and Obaseki in Benin, Nigeria. ${ }^{10}$ This is probably because the clinicians do not feel that these information are of immense benefit to the diagnosis being awaited. It is a general observation that certain disease may be more common in a particular locale, and this is important in increasing the index of suspicion for such disease by the pathologist. The implication of such information on medical research cannot be overemphasized.

About $8.3 \%$ of the laboratory request forms did not have hospital numbers documented, which is lower that $50 \%$ and $54.2 \%$ reported by Nwafor and Obioha ${ }^{5}$; and Forae and Obasek $\mathrm{i}^{10}$ respectively. Absence of hospital number can negatively affect the chances of retrieving information from the case notes of these patients if the need arises.

Documentation of time of collection is relevant in quality assessment especially in working towards reducing turn-around time or other forms of laboratory quality assessment. ${ }^{8}$ Our report is however lower than $40.6 \%$ and $84.3 \%$ of omitted days and minute time in Forae and Obaseki's report. ${ }^{10}$

In this study, we noticed that clinical information is inadequate in $36.1 \%$ of the cases which is lower than the $63.6 \%$ reported by Forae and Obaseki ${ }^{10}$ but higher than $2.4 \%$ and $20 \%$ reported respectively by Naklhel and Zarbo; ${ }^{12}$ and Muhammad et al. ${ }^{8}$ respectively. Studies has shown that provision of adequate clinical information improves the pathologist efficiency by eliminating unnecessary ancillary investigation, narrowing down his diagnostic options and tailoring his report to what the clinician needs. ${ }^{13}$ This is further collaborated with proofs of changes in pathology diagnosis, after clinical information, which were initially lacking were provided to the pathologist. ${ }^{14}$ Evidence also abound of positive impact of adequate clinical information on turn-around time. ${ }^{8,12}$ In a review by Troxell and Sabella, inadequate clinical information was observed as the root cause of $20 \%$ of diagnostic errors in surgical pathology. ${ }^{15}$ In an analysis by McBroom and Ramsay, $10 \%$ of specimen considered for Pathologist peer review were because of their poor clinical history. ${ }^{16}$

Originator name and signature were not documented in $13.7 \%$ and $27.4 \%$ of cases. Ninety seven point five percent of request forms did have the originators' phone number. Communicating with clinician would be so easy with telephone number. It also supports the view of most surgical pathologists that a lot of clinicians do not understand the working of surgical pathologist. ${ }^{10}$ In developing countries 
were Laboratory information system are hardly available ${ }^{17}$ telephone can serve as a vital tool in transmitting information and images across the divide, both in helping clinician appreciate the limitations of histopathology practice and in extracting more information from the clinician where and when necessary.

\section{CONCLUSIONS}

Clinicians play vital role in the surgical pathology process which if sub-optical could have undesirable consequences. There is therefore a need to increase the awareness of the clinician of the limitations and complexity of surgical pathology process as well as the consequences of their inaction. Adopting strict criteria for accepting surgical specimen, continuous education and interfacing with clinician, adopting computerizing information management and introduction of non-conformity registrar are possible ways of closing this gap. The dividend will be a better service delivery by pathologist, a more satisfied clinician and a positive health outcome for the patient.

\section{Acknowledgment}

The author is grateful to staff of the department of Pathology of Delta State University Teaching Hospital, Nigeria.

\section{Conflict of interests: None}

\section{REFERENCES}

1. Biswas J. As is our Pathology, So is our Practice. Middle East Afr J Ophthalmol. 2011;18: 259-60. Crossref

2. Badrick T. Evidence-Based Laboratory Medicine. Clin Biochem Rev. 2013; 34: 43-6. Website

3. Rosai J, editor. Rosai and Ackerman's Surgical Pathology. 10th ed. Philadelphia: Mosby, Elsevier; 2011. p. 1-20.

4. Akinfenwa T Atanda and Solomon Raphael. Role of surgeons in determining outcome of histopathology specimens. Niger J Surg. 2013;19:68-72. Crossref

5. Nwafor CC, Obioha K. Preanalytic determinants of surgical pathology practice in Uyo. Saudi J Health Sci 2018;7:33-38. Crossref

6. Suleiman DE. Pathologist-clinician collaboration: A marriage of necessity toward improving the quality of patient care. Ann Nigerian Med. 2015;9:1-3. Crossref

7. Lester SL. Manual of surgical pathology. 3rd edition.Elsevier. 2010. p.22.

8. Hammad Ali: Impact of clinical information on TAT in surgical pathology. Cureus 2018;10:2596. Crossref
9. Muhammad AS, Sajid M, Nadira M, Shahid J, Muhammad L. Clinician's responsibility in pre-analytical quality assurance of histopathology. Pak J Med Sci. 2007;23:720-3. Website

10. Forae DD, Obaseki DE. Adequacy of clinical information supplied by clinicians for histopathologic diagnosis: The university of Benin teaching hospital experience. New Nigerian Journal of Clinical Research. 2017;6:12-5. Crossref

11. Westergaard D, Moseley P, Sørup FKH, Baldi P, Brunak S. Populationwide analysis of differences in disease progression patterns in men and women. Nature Communications 2019;10:666. Crossref

12. Nakhleh RE, Gephardt G, Zarbo RJ. Necessity of clinical information in surgical pathology: a College of American Pathologists Q-Probes study of 771475 surgical pathology cases from 341 institutions. Arch Pathol Lab Med 1999;123:615-9. Crossref

13. Burton JL, Stephenson TJ .Are clinicians failing to supply adequate information when requesting a histopathological investigation? J Clin Pathol. 2001;54:806-8. Crossref

14. Ferrara G, Argenyi Z, Argenziano G. The influence of clinical information in the histologic diagnosis of melanocytic skin neoplasms. PLOS ONE 2009;4:e5375. Crossref

15. Troxel DB, Sabella JD. Problem areas in pathology practice: Uncovered by a review of malpractice claims. Am J Surg Pathol 1994;18:821-31. Crossref

16. McBroom HM, Ramsay AD. The clinicopathological meeting. A means of auditing diagnostic performance. Am J Surg Pathol 1993;17:75-80. Crossref

17. Uchendu OJ.Challenges of Practicing Histopathology in a developing country: The Nigerian Perspective. Annals of Biomedical Sciences 2013;12:59-65. Website 